\title{
Secondary syphilis resembling erythema annulare centrifugum
}

\author{
Siham Mansouri, ${ }^{\ominus}$ Sara Mai, Karima Senouci, Badr Hassam
}

Dermatology, CHU Ibn Sina, Rabat, Morocco

\section{Correspondence to \\ Dr Siham Mansouri,} siham-mnsr@hotmail.fr

Accepted 10 May 2019

\section{DESCRIPTION}

An 80-year-old man, with no known medical history or previous medication, presented with a 3-month history of asymptomatic erythematous scaly plaques over his arms, abdomen and legs. He denied any systemic complaints. Prior to our admission, the patient was diagnosed with superinfected eczema and was treated with topical dermocorticoids and oral antibiotics for 10 days without any improvement. Dermatological examination revealed facial erythema related to rosacea, erythematous scaly patches with crusty edges affecting the upper (figure 1) and lower limbs (figure 2), the back and the abdomen, nodular lesions located on the lower limbs and target lesions on the thighs (figure 3). The genital, anal and orolabial examination was normal. No systemic symptoms were observed.

The initial diagnostic consideration was lymphoma, lupus, eczema or cutaneous drug hypersensitivity. A skin biopsy specimen was taken, revealing hyperkeratosis and perivascular lymphohistiocytic infiltrate. Biological and immunological tests were normal.

On further questioning, the patient admitted he had several unprotected sex with female partners in the last few months. The patient could not remember having had any previous genital or extragenital chancre. Screening serum tests for the different sexually diseases were performed and found: a venereal disease research laboratory (VDRL) of $1 / 8$ controlled to $1 / 16$, and Treponema pallidum haemagglutination assay titer of 1280 UI. Antihuman immunodeficiency virus antibodies, hepatitis $\mathrm{C}$ and hepatitis B serology were negative. Blood and urine cultures were negative. He was treated with an intramuscular injection of benzathine benzylpenicillin 2.4 million units as a single dose. The patient was instructed to use condoms in the future and to contact all persons with whom he had sexual contact within the last year, so that they could be evaluated for sexually transmitted diseases. No Jarisch-Herxheimer reaction occurred

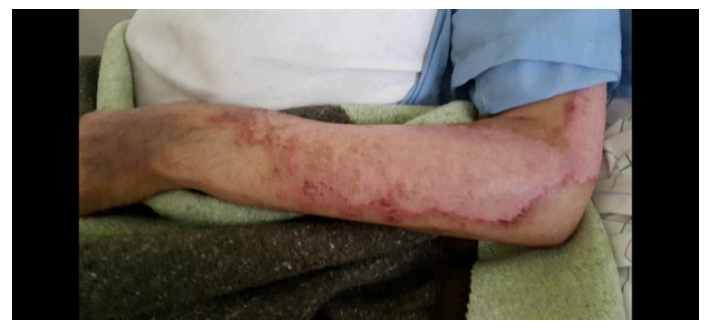

Figure 1 Erythematous scaly patches of the upper limbs.

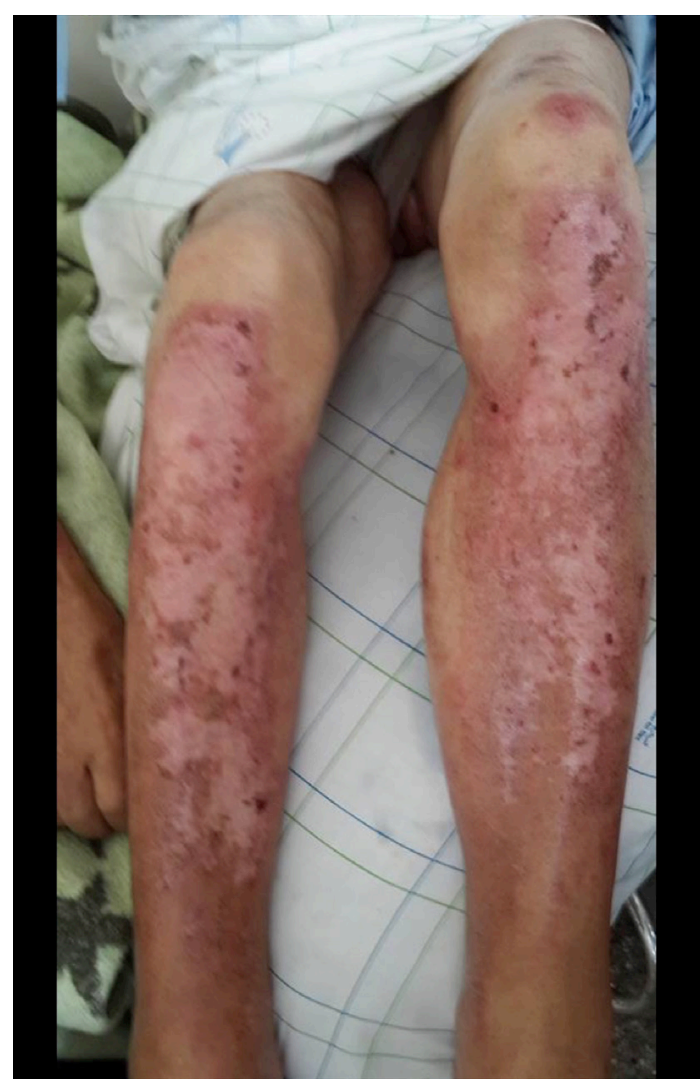

Figure 2 Erythematous scaly patches of the lower limbs.

and the lesions cleared within 2 months with resident hyperpigmentation and hypopigmentation. The VDRL test reverted to negative.

Syphilis is a sexually transmitted infection caused by the spirochete T. pallidum. Although the syphilis is a controllable disease, it continues to be a major public health problem worldwide. ${ }^{1}$ While primary syphilis, often presents with the classical painless chancre; secondary syphilis is a

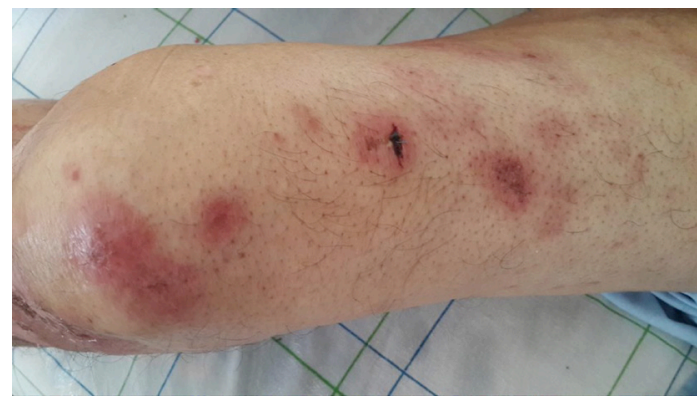

Figure 3 Target lesions and nodules on the thighs. 
notorious 'great imitator' due to its variability of presentation and imitation of other diseases. Syphilis lesions are usually asymptomatic and may undergo spontaneous remission. In addition, these patients can be asymptomatic for various years before developing tertiary syphilis and therefore affecting severely other organs, leading in some cases to life-threatening complications. $^{2}$

The most common cutaneous presentation for secondary syphilis is a generalised, non-pruritic, papulosquamous eruption varying from pink to brown; but it can present with different atypical features, especially in the immunocompromised patient: macular, maculopapular, papulosquamous, ${ }^{3}$ nodular, ${ }^{1}$ psoriasiform, ${ }^{4}$ pustular, impetigo-like, ${ }^{5}$ vesicular, corymbose, ${ }^{2}$ lenticular, annular, ${ }^{67}$ follicular, ulceronecrotic, granulomatous and pigmentary lesions. ${ }^{28}$ Mucous membrane lesions are infectious. ${ }^{8}$

Moreover, other organs may be affected: lymphoreticular, ophthalmological, musculoskeletal, haematological, renal, hepatic, cardiovascular and gastric. ${ }^{8}$

\section{Learning points}

- Our case was characterised by unusual manifestations and contribute to, raising the awareness of physicians about atypical clinical aspects of syphilis.

- Failure to recognise and appropriately treat this infection may have threatening complications.

- It is worth testing for syphilis in patients with unexplained cutaneous rash, especially those who failed the standard therapy.
The positivity of serological tests and histology may be helpful in atypical cases, but histological features of secondary syphilis are polymorphic.

Syphilis has devastating complications if left untreated. It is avoidable if it is treated with effective antibiotics.

Contributors SiM: the doctor who took care of the patient. SaM: the doctor who collaborated in the care of the patient. KS: the professor who is responsible for therapeutic decisions of the patient. BH: the dermatology department head who is responsible for all professional and scientific activities.

Funding The authors have not declared a specific grant for this research from any funding agency in the public, commercial or not-for-profit sectors.

Competing interests None declared.

Patient consent for publication Obtained.

Provenance and peer review Not commissioned; externally peer reviewed.

\section{REFERENCES}

1 Dănescu SA, Szolga B, Georgiu C, et al. Unusual manifestations of secondary syphilis: case presentations. Acta Dermatovenerol Croat 2018;26:186-8.

2 Eyer-Silva WA, Souza VPB, Silva G, et al. Secondary syphilis presenting as a corymbiform syphilide: case report and review. Rev Inst Med Trop Sao Paulo 2018;60:e40.

3 Genovese G, Nazzaro G, Coggi A, et al. Secondary syphilis masquerading as lupus vulgaris in an HIV-infected patient: A diagnosis suggested by histology. Int I STD AIDS 2018;29:1454-6.

4 Daroach M, Vinay K, Kumaran MS. Pseudo circinate balanitis: great masquerader lives. Postgrad Med J 2019:postgradmedj-2018-136327.

5 Li QF, Han K, Gurung I, et al. Secondary syphilis presented with impetigo-like lesions: a rare case report. Int I Dermatol 2018;57:e141-2.

6 Wong GW. A large annular scaly plaque. Australian Journal of General Practice $2018 ; 47$

7 Liu ZH, Chen JF. Unusual huge erythema annulare centrifugum presentation of second syphilis. QJM 2014;107:231-2.

8 Domantay-Apostol GP, Handog EB, Gabriel MT. Syphilis: the international challenge of the great imitator. Dermatol Clin 2008;26:191-202.

Copyright 2019 BMJ Publishing Group. All rights reserved. For permission to reuse any of this content visit

https://www.bmj.com/company/products-services/rights-and-licensing/permissions/

BMJ Case Report Fellows may re-use this article for personal use and teaching without any further permission.

Become a Fellow of BMJ Case Reports today and you can:

- Submit as many cases as you like

- Enjoy fast sympathetic peer review and rapid publication of accepted articles

- Access all the published articles

Re-use any of the published material for personal use and teaching without further permission

Customer Service

If you have any further queries about your subscription, please contact our customer services team on +44 (0) 2071111105 or via email at support@bmj.com.

Visit casereports.bmj.com for more articles like this and to become a Fellow 